\title{
DEFAULT RATE IN THE CZECH \\ REPUBLIC DEPENDING ON SELECTED MACROECONOMIC INDICATORS
}

\author{
Radmila Stoklasová
}

\section{Introduction}

Since the late 1980s, the Czech Republic has undergone the transformation process from a centrally planned economy to a market economy. The modernization of the country's financial sector is a fundamental condition for economic growth. The beginning of the transformation was associated with a rapid increase in credit activity. There was a decrease in the growth rate in the second half of the 1990s, followed by a decrease in the volume of lending. The volume of lending has increased again and the number of 'bad' credits has increased also since 2000.

The model-estimated variable of credit risk or default can be defined in several ways. Generally, a default event is defined as a violation of payment discipline. When evaluating credit risk, it is usually a 12-month probability of default, i.e. the default occurs within a 12-month period from a set moment. In this article, the default rate is defined by the proportion of newly created 'bad' credits to the total volume of credit in the economy. Data source was the ARAD database of the Czech National Bank. The data used have the character of a quarterly time series in the period from 2005Q1 to 2017Q1. EViews software version 9 was used for the calculations.

The aim of the article is to analyse which determinants influence the defaults in the Czech Republic in the long term and to prepare a model based on this analysis to estimate the expected proportion of the default rate depending on the development of selected macroeconomic indicators.

The article is structured as follows. The first section presents a brief overview of the theoretical approaches to modelling the default rate. The second section discusses the time series used to estimate the model as well as the econometric methods used. The third section describes and estimates the structural model of the default rate. The fourth section discusses the results of modelling the default rate in the Czech Republic. The results are summarized in the conclusion.

\section{Theoretical Background}

Macroeconomic models are motivated by observed assumptions that default rates for different entities rise during the recession. This fact led to the implementation of econometric models aimed at explaining the default rate using macroeconomic indicators. Estimating the default rate is at the forefront of both the professional and academic public.

Chan-Lau (2006) distinguished four approaches to modelling the probability of default. In particular, he considers macroeconomicbased models, models based on accounting data, rating-based models and hybrid models. Macroeconomic-based models have several advantages, such as the ability to apply these models to create stress scenarios and the easy availability of macroeconomic data. On the contrary, Simons and Rolwes (2009) state the disadvantages of these models. For example, it is necessary to work with a time series longer than one economic cycle, another disadvantage is the inaccuracy of these models in terms of instability of model parameters over time, as reported in Lucas (1976). According to Simons and Rolwes (2009), macroeconomic models can be divided into exogenous and endogenous, with the difference between them being based on a different concept of macroeconomic variables in the model.

This paper deals with endogenous models based on the vector autoregressive (VAR) model that is used when working with multidimensional time series, e.g. Enders (2010). VAR models were used for modelling the probability of default by, for example, 
Alessandri et al. (2009) or Hamerle et al. (2011) in their articles. Blaschke et al. (2001) examined how the share of outstanding credits depends on nominal interest rates, inflation and GDP growth. These models are based on the assumption of credit quality sensitivity to changes in the economic cycle. It is important to use macroeconomic and financial variables, which can be expected to have a greater impact on credit risk when designing the model. Variables such as economic growth, unemployment and interest rates can affect credit risk. Drehmann (2009) addresses the selection of suitable model variables. Marcucci and Quagliariello (2008) applied the VAR approach for credit risk modelling and four macroeconomic variables: GDP, inflation, interest rates and exchange rates. Hamerle et al. (2011) used classic variables such as GDP growth, unemployment, inflation, but also stock market variables, e.g. Dow Jones Industrial Average.
Most central banks work with some forms of stress testing, however, only some use a macroeconomic credit model. If central banks use the macroeconomic credit models, they are mostly a macroeconomic credit model, such as the United Kingdom, Germany, Belgium or Finland. In the case of Finland, it is a macroeconomic model based on logistic regression, which explains the relation of the default rate to the individual sectors of the economy on the basis of macroeconomic indicators. This model considers real GDP, nominal interest rates and the indicator of indebtedness of each of the sectors examined as explanatory variables. The default rates are modelled by the proportion of company bankruptcies in the total number of companies for the given economy sector.

The issues associated with these models are developing rapidly, yet there is no clear consensus on which of the model types are the best, as Jakubík (2007) pointed out.

\section{Tab. 1: Description of variables}

\begin{tabular}{|c|c|c|}
\hline $\begin{array}{c}\text { Variable } \\
\text { Designation }\end{array}$ & Description of Variable & Source \\
\hline $\mathbf{Y}$ & $\begin{array}{l}\text { The default rate is defined as the proportion of newly created 'bad' } \\
\text { loans to the total volume of loans. }\end{array}$ & ARAD \\
\hline GDP & $\begin{array}{l}\text { Gross domestic product at current prices in millions of CZK. Lower } \\
\text { GDP growth means lower sales growth and it is more difficult for } \\
\text { businesses to generate profits. For this reason, the default rate is } \\
\text { expected to be higher with lower GDP. }\end{array}$ & ARAD \\
\hline CPI & $\begin{array}{l}\text { Consumer Price Index }(2005=100) \text {. It is assumed that the rise in } \\
\text { price indices (inflation growth) will cause an increase in the default } \\
\text { rate. }\end{array}$ & ARAD \\
\hline IR & $\begin{array}{l}\text { Real interest rate. It is assumed that if these rates are high, there is } \\
\text { a higher default rate. }\end{array}$ & ARAD \\
\hline INE & $\begin{array}{l}\text { Index of the nominal effective exchange rate of the Czech crown } \\
(2015=100), \text { weight: } 2015 \text { foreign trade turnover in \%. The unam- } \\
\text { biguous impact of this variable on the default rate is not expected. }\end{array}$ & KURZYCZ \\
\hline BRENT & $\begin{array}{l}\text { Oil price index }(2005=100) \text {. Growth in oil prices is reflected in the } \\
\text { growth of fuel, the price of which is entering most of the production. } \\
\text { We can expect an increase in default with the increase in oil prices. }\end{array}$ & $\begin{array}{l}\text { PETROLEUM \& } \\
\text { OTHER LIQUIDS }\end{array}$ \\
\hline UN & $\begin{array}{l}\text { Unemployment rate. A positive long-term and short-term } \\
\text { relationship is assumed. }\end{array}$ & ARAD \\
\hline M2 & $\begin{array}{l}\text { Monetary aggregate } \mathrm{M} 2 \text { in millions of CZK. In the short term, the } \\
\text { money supply decreases the interest rate and a reduction in the } \\
\text { default rate can be expected. In the long run, a positive relationship } \\
\text { between money supply and the default rate is expected due to } \\
\text { increases in price. }\end{array}$ & ARAD \\
\hline
\end{tabular}


Many studies show that the transmission of macroeconomic changes is in many cases more sensitive and faster in the CEE countries than in the old EU member countries.

\section{Data and the Methods}

Quarterly data for the period from 2005/Q1 to 2017/Q1 were used for the calculations. The ARAD database of the Czech National Bank was the primary data source. The description of individual variables, together with the data source, is shown in Tab. 1. All values are considered in logarithmic terms. The selection of variables was done according to Jakubík (2007) and Simons and Rolwes (2009). EViews software version 9 was used for the calculations.

All of these variables were seasonally adjusted, in addition by logarithmic transformation.

\subsection{VAR/VECM Model}

The Vector Autoregressive Model (VAR) and the Vector Error Correction Model (VECM) make it possible to express and analyse a simultaneous relation between the variables. Arlt (1999) states that VAR analysis is based on the idea that all the variables used to analyse a selected dependency are random and simultaneously dependent. This means that the model structure contains only endogenous variables (except the deterministic components of the model), with their maximum delay time being the same.

The $\operatorname{VAR}(p)$ model can be written in the following form (1), assuming that $C_{s}=0$ for $s>p$ :

$$
Y_{t}=\eta+\sum_{s=1}^{p} C_{s} Y_{t-s}+U_{t}
$$

where $\eta$ is vector of constants; $Y$ is $k$ of model variables; $U_{t}$ is a vector of random model components; $C_{s}$ is a parameter matrix of endogenous variables in the VAR space, delayed by $s$ periods.

By including a long-term relation to (1), VECM is obtained in the following form:

$$
\Delta Y_{t}=\eta+\Pi Y_{t-1}+\sum_{s=1}^{p} C_{s} \Delta Y_{t-s}+U_{t}
$$

where $\eta$ is vector of constants; $Y_{t-1}$ is $k$ of model variables; $\Delta Y$ is the first difference $k$ of model variables; $U_{t}^{t}$ is a vector of random model components; $\Pi$ is a matrix of long-term relation; $\Pi=\alpha \beta^{T}$, where $\alpha$ is estimated parameters that express the rate of system adaptation and $\beta$ is a cointegrating vector or a matrix of cointegrating vectors; $C_{s}$ is a parameter matrix of endogenous variables in the VAR space, delayed by $s$ periods.

The model can again include, if necessary, the deterministic component vector $D_{t}$ with the corresponding matrix of its parameters $\Gamma$.

Kočenda and Černý (2007) state that it is assumed that the relation between the included variables is simultaneous and symmetric when constructing a VAR model. A prerequisite for deriving the VAR model is the stationary nature of all time series.

Time series can be analysed based on their short-term and long-term relations. If there is only a short-term relation between the time series, the VAR model is a sufficient tool for analysing this relation. If a long-term relation exists between selected time series, the VECM model can be used for analysis. The VECM model simultaneously captures and expresses both short-term and long-term relations. The VECM model is based on a cointegration approach that models non-stationary time series the long-term relation of which is expressed through the error correction mechanism.

The AIC (Akaike Information Criterion) and SBC (Schvarz Bayesian Criterion) information criteria are used to determine the maximum length of delay for each time series. Kočenda and Černý (2007) state the following relations for the calculation of these information criteria:

$$
\begin{aligned}
& A I C=\log \left(\frac{R S S}{T}\right)+\frac{2 K}{T} \\
& S B C=\log \left(\frac{R S S}{T}\right)+\frac{\log (T) K}{T}
\end{aligned}
$$

where RSS residual variance; $T$ number of observations; $K$ number of endogenous variables.

The most appropriate delay of each time series is selected based on the minimum values of these criteria.

Most time series in macroeconomics and finance are non-stationary or integrated with order I(1), as stated in Engle and Granger (1987). I(1) denotes a time series the first differences of which are stationary. That is why data stationarity testing or unit root tests are 
performed. The Augmented Dickey-Fuller test (ADF) is often used in the literature. The ADF test allows you to test the presence of a unit root based on three models $A, B, C$. Model A represents a random walk model, Model B contains a constant $(\mu)$, and Model $\mathrm{C}$ contains a constant $(\mu)$ and a trend component $(t)$. Test models are defined as follows:

Model A:

$$
\Delta y_{t}=\gamma y_{t-1}+\sum_{i=1}^{K} \rho_{i} \Delta y_{t-1}+\varepsilon_{t}
$$

Model B:

$$
\Delta y_{t}=\mu+\gamma y_{t-1}+\sum_{i=1}^{K} \rho_{i} \Delta y_{t-1}+\varepsilon_{t}
$$

Model C:

$$
\begin{aligned}
& \Delta y_{t}=\mu+\beta t+\gamma y_{t-1}+ \\
& +\sum_{i=1}^{K} \rho_{i} \Delta y_{t-1}+\varepsilon_{t}
\end{aligned}
$$

The determination of the order of integration of the individual time series is based on the zero hypothesis: $H_{0}: \gamma=0$, which states that a time series contains a unit root, i.e. that the nonsystematic component of time series is type $\mathrm{I}(1)$. An alternative hypothesis is placed against the zero hypothesis: $H_{1}: \gamma<0$, which states that a time series is stationary.

\subsection{Cointegration Analysis}

Cointegration analysis is based on the integrated processes that were first comprehensively addressed by Box and Jenkins. The cointegration analysis examines short-term dynamics and long-term relations between variables. Each system is subject to constant shocks, so it does not reach equilibrium in the short run. Nevertheless, there may be a relation between the time series that can be considered as equilibrium in the long run. Arlt (2003) states that Engle and Granger developed a simple cointegration test based on a residual stationarity test. The Engle and Granger approach can be described as a classic approach. The problem arises when analysing the relation between more than two variables. In this case, it is better to apply Johansen's approach. The Johansen's approach advantage is that, in addition to the cointegration test, it is possible to explicitly address the potential existence of multiple cointegrating vectors.

The cointegration analysis is based on the search for non-zero, the so-called eigenvalue, values of the matrix of long- term relations $(\Pi)$. Based on this testing, the number of cointegrating vectors in the VECM model is determined. The matrix of long-term relations $(\Pi)$ is equal to the number of its nonzero eigenvalue values. This approach uses two test criteria: Eigenvalue statistics and Trace statistics.

$$
\begin{aligned}
& \lambda_{M A X}(r+1)=-T \ln \left(1-\lambda_{r+1}\right) \\
& \lambda_{\text {TRACE }}(r)=-T \sum_{i=r+1}^{N} \ln \left(1-\lambda_{i}\right)
\end{aligned}
$$

The first criterion (8) (eigenvalue statistics) tests the validity of the zero hypothesis with the existence of exactly $r$ cointegration vectors versus an alternative hypothesis expressing the occurrence of $r+1$ cointegration vectors. The second test criterion (9) (trace statistics) verifies the validity of the zero hypothesis with the existence of maximum $r$ cointegration vectors versus an alternative hypothesis that there are more than $r$ vectors. The results of the second test criterion are shown in Tab. 4. These methods are also used in Stavárek's and Vodová's article (2010).

Based on the tests, it is possible to identify 3 cases:

1. Matrix $\Pi$ has a full rank: the relation between time series is stationary; there is no long-term relation between them. The VAR model will be used.

2. Matrix $\Pi$ is zero: time series are nonstationary but there is no long-term relation between them, i.e. that they are not cointegrated. Therefore, it is appropriate to differentiate the time series and estimate the VAR model.

3. Matrix $\Pi$ has not full rank or is not zero: time series are non-stationary and cointegrated. The VECM model should be used to analyse the relation.

\subsection{Impulse-Response Analysis}

Impulse-response analysis allows analysis of both the short-term and long-term relations between the analysed variables based on the derived model. Arlt (1999) states that the impulse-response analysis is related to the question of what reaction in one time series will be caused by an impulse in another time series within a system that contains multiple time series. This is the study of the relation between two one-dimensional time series in a multidimensional system. 


\section{Econometric Default Rate Model}

The third chapter deals with the estimation and testing of the default rate model depending on the selected economic indicators listed in Tab. 1. The chapter is divided into four parts. First, a stationarity of VAR model variables is tested and the order of the VAR model is determined. As the second step, the cointegration relationships for the $\operatorname{VAR}(p)$ model are tested using the Johansen's method and a number of cointegration relationships is determined. There is to estimate a $\operatorname{VECM}(p)$ model assuming the existence of $r$ cointegration relationships. There are equations for long-run equilibrium relationships. The third part deals with model diagnostics. The last part deals with the identification of short-term relationships (Granger causality).

\subsection{VAR Model}

The preparatory phase of estimating the VAR model is testing the stationarity of variables included in the model or their first differences. The test results for all variables are provided in Tab. 2. The Dickey-Fuller test (ADF) was used to test the stationarity. The second column provides information on the model type of testing the unit root $(\mathrm{n}=\mathrm{no}$ trend and level constants $/ \mathrm{c}=$ constant $/ \mathrm{c}+\mathrm{t}=$ level constant and trend), the third column contains the calculated T-statistics; the following column contains the corresponding level of statistical significance. The last column includes the result of testing: $\mathrm{N}=$ non-stationary ( $\mathrm{H} 0$ not rejected), $\mathrm{S}=$ stationary $(\mathrm{H} 0$ rejected $)$.

The variables (BRENT, GDP, INE, IR, UN, Y) for the VAR model exhibit the properties of first-

Tab. 2: Testing the unit root of the variables in levels and their first differences
\begin{tabular}{c|c|c|c|c|c|c|c|c|c} 
variable & $\mathbf{n} / \mathbf{c} / \mathbf{c}+\mathbf{t}$ & $\mathrm{T}-\mathrm{stat}$ & $\mathbf{p}$-value & result & variable & $\mathbf{n} / \mathbf{c} / \mathbf{c}+\mathbf{t}$ & T-stat & $\mathbf{p}$-value & result \\
\hline$B R E N T$ & $\mathrm{c}+\mathrm{t}$ & -2.393 & 0.378 & $\mathrm{~N}$ & $D(B R E N T)$ & $\mathrm{n}$ & -6.672 & 0.000 & $\mathrm{~S}$ \\
\hline$C P I$ & $\mathrm{c}+\mathrm{t}$ & -1.486 & 0.819 & $\mathrm{~N}$ & $D(C P I)$ & $\mathrm{c}$ & -2.861 & 0.058 & $\mathrm{~N}$ \\
\hline$G D P$ & $\mathrm{c}+\mathrm{t}$ & -1.763 & 0.706 & $\mathrm{~N}$ & $D(G D P)$ & $\mathrm{c}$ & -4.593 & 0.001 & $\mathrm{~S}$ \\
\hline$I N E$ & $\mathrm{c}+\mathrm{t}$ & -1.784 & 0.696 & $\mathrm{~N}$ & $D(I N E)$ & $\mathrm{n}$ & -6.981 & 0.000 & $\mathrm{~S}$ \\
\hline$I R$ & $\mathrm{c}+\mathrm{t}$ & -3.104 & 0.117 & $\mathrm{~N}$ & $D(I R)$ & $\mathrm{n}$ & -2.783 & 0.006 & $\mathrm{~S}$ \\
\hline$M 2$ & $\mathrm{c}+\mathrm{t}$ & -2.735 & 0.228 & $\mathrm{~N}$ & $D(M 2)$ & $\mathrm{n}$ & -0.827 & 0.351 & $\mathrm{~N}$ \\
\hline$U N$ & $\mathrm{c}+\mathrm{t}$ & -1.511 & 0.812 & $\mathrm{~N}$ & $D(U N)$ & $\mathrm{n}$ & -3.232 & 0.002 & $\mathrm{~S}$ \\
\hline$Y$ & $\mathrm{c}+\mathrm{t}$ & -2.665 & 0.255 & $\mathrm{~N}$ & $D(Y)$ & $\mathrm{n}$ & -3.411 & 0.001 & $\mathrm{~S}$ \\
\hline
\end{tabular}

Source: own calculations

order non-stationarity, i.e. I(1); therefore, the long-run cointegration relationships may exist between these variables. The VAR model with variables BRENT, GDP, INE, IR, UN, Y did not meet the assumptions: the residual component is not correlated; residual component heteroscedasticity and residual component non-normality the were not demonstrated. Therefore, the IR variable has been deleted from further considerations.

This part of the article describes the estimation of the $\operatorname{VAR}(p)$ model. The model estimation includes a determination of $p$ order for delayed variables (BRENT, GDP, INE, UN, $Y$ ) in a vector autoregressive model. This delay level is usually the same for all VAR model equations. Given the set of quarterly data, the maximum delay time of 4 was considered. Tab. 3 summarizes the results based on the minimization of selected criteria: FPE: Final prediction error, AIC: Akaike information criterion, SC: Schwarz information criterion, $H Q$ : Hannan-Quinn information criterion and LR: likelihood ratio, which is based on the principle of maximum likelihood.

Most of these tests recommend a delay order of 1 except for LR and AIC criterions which recommend the $\operatorname{VAR}(4)$ model. The $\operatorname{VAR}(1)$ model was chosen for further considerations.

\subsection{VECM}

This part deals with the testing of the number of cointegration relationships in the VAR(1) model for the endogenous variables (BRENT, GDP, 


\section{Talo. 3: VAR lag order selection criteria}

\begin{tabular}{c|c|c|c|c|c|c} 
Lag & LogL & LR & FPE & AIC & SC & HQ \\
\hline 0 & 180.3492 & NA & $2.84 \mathrm{e}-10$ & -7.793296 & -7.592556 & -7.718462 \\
\hline 1 & 439.9018 & 449.89120 & $6.25 \mathrm{e}-15^{*}$ & -18.21786 & $-17.01341^{*}$ & $-17.76885^{*}$ \\
\hline 2 & 472.7534 & 49.64248 & $8.50 \mathrm{e}-15$ & -18.56682 & -16.35868 & -17.74364 \\
\hline 3 & 492.1373 & 24.98372 & $8.98 \mathrm{e}-15$ & -18.31721 & -15.10537 & -17.11987 \\
\hline 4 & 529.6096 & $39.97047^{*}$ & $6.48 \mathrm{e}-15$ & $-18.87154^{*}$ & -14.65599 & -17.30003 \\
\hline
\end{tabular}

Source: own calculations

Note: * indicates lag order selected by the criterion.

\section{Tab. 4: Cointegration analysis}

\begin{tabular}{l|c|c|c|c}
\multicolumn{1}{c|}{$\begin{array}{c}\text { Hypothesized } \\
\text { No. of CE(s) }\end{array}$} & Eigenvalue & Trace Statistic & $\begin{array}{c}\mathbf{0 . 0 5} \text { Critical } \\
\text { Value }\end{array}$ & p-value \\
\hline None * & 0.615161 & 83.64081 & 60.06141 & 0.0002 \\
\hline At most 1 & 0.325051 & 38.75909 & 40.17493 & 0.0690 \\
\hline At most 2 & 0.254341 & 20.28256 & 24.27596 & 0.1470 \\
\hline At most 3 & 0.125439 & 6.488675 & 12.32090 & 0.3790 \\
\hline At most 4 & 0.004016 & 0.189123 & 4.129906 & 0.7183 \\
\hline
\end{tabular}

Source: own calculations

Note: ${ }^{*}$ denotes rejection of the hypothesis at the 0.05 level.

INE, UN, Y) using the Johansen's method, as shown in Johansen (1995). Tab. 4 confirms the existence of 1 cointegration relationship for $\operatorname{VECM}(1)$. This is a model that includes a limited level constant and does not include a trend component.

The test in Tab. 4 confirms the existence of one cointegration relationship. The estimation led to a cointegration equation (10). Standard errors are listed in parentheses.

$$
\begin{gathered}
Y=-0.169 \cdot B R E N T+2.906 \cdot G D P- \\
(0.355) \quad(0.625) \\
-9.083 \cdot I N E+1.856 \cdot U N \\
(2.103) \quad(0.363)
\end{gathered}
$$

The cointegration equation shows that the default rate is positively affected in the long term by GDP and the unemployment rate. GDP growth causes an increase in the default rate in the long run, which is in contradiction with the stated assumption. The positive relationship between the default rate and the unemployment rate is in line with the stated assumption. The equation also shows that there is a negative relationship between the default rate and the Brent crude oil price. This means that the increase in the oil price causes a reduction in the default rate in the long run, which is in contradiction with the assumption. There is also a negative relationship between the default rate and the effective exchange rate of the Czech crown.

Because of the error correction vector mechanism, deviations from the equilibrium state are corrected by a series of partial shortterm adaptations. This is also supported by the VECM specification, which gives room for short-term dynamics. The VECM is a tool for examining short-term deviations needed to achieve a long-term equilibrium between two variables. The VECM estimation for the cointegration relationship found is in Tab. 5 . 
Tab. 5: Estimates VECM

\begin{tabular}{l|c|c|c|c|c} 
Error Correction & $\mathbf{D}(\mathbf{Y})$ & $\mathbf{D}(\mathbf{B R E N T})$ & $\mathbf{D}(\mathbf{G D P})$ & $\mathbf{D}(\mathbf{I N E})$ & $\mathbf{D}(\mathbf{U N})$ \\
\hline CointEq1 & -0.006595 & -0.059641 & $-0.013141^{* * *}$ & $-0.013679^{* *}$ & 0.013037 \\
& $(0.01254)$ & $(0.05518)$ & $(0.00210)$ & $(0.00632)$ & $(0.01266)$ \\
& {$[-0.52602]$} & {$[-1.08089]$} & {$[-6.26481]$} & {$[-2.16406]$} & {$[1.02975]$} \\
\hline $\mathrm{D}(\mathrm{Y}(-1))$ & $0.301665^{* *}$ & -0.715164 & $-0.053067^{* *}$ & -0.044413 & 0.154697 \\
& $(0.14112)$ & $(0.62109)$ & $(0.02361)$ & $(0.07115)$ & $(0.14251)$ \\
& {$[2.13767]$} & {$[-1.15146]$} & {$[-2.24747]$} & {$[-0.62420]$} & {$[1.08554]$} \\
\hline D(BRENT(-1)) & -0.005243 & 0.084706 & -0.004680 & $0.040611^{* *}$ & -0.040175 \\
& $(0.03806)$ & $(0.16751)$ & $(0.00637)$ & $(0.01919)$ & $(0.03843)$ \\
& {$[-0.13776]$} & {$[0.50569]$} & {$[-0.73498]$} & {$[2.11634]$} & {$[-1.04533]$} \\
\hline D(GDP(-1)) & $-0.585716^{*}$ & -3.252616 & -0.165714 & -0.635495 & -0.596749 \\
\hline & $(0.30870)$ & $(3.99940)$ & $(0.15204)$ & $(0.45816)$ & $(0.91764)$ \\
\hline & {$[-1.89736]$} & {$[-0.81328]$} & {$[-1.08992]$} & {$[-1.38705]$} & {$[-0.65031]$} \\
\hline D(INE(-1)) & $-0.574067^{*}$ & -0.536963 & $0.158224^{* * *}$ & -0.143895 & -0.463915 \\
\hline & $(0.29817)$ & $(1.31233)$ & $(0.04989)$ & $(0.15034)$ & $(0.30111)$ \\
\hline & {$[-1.92527]$} & {$[-0.40917]$} & {$[3.17147]$} & {$[-0.95714]$} & {$[-1.54069]$} \\
\hline D(UN(-1)) & $0.378255^{* *}$ & 0.518085 & -0.045677 & -0.082898 & $0.383359^{* *}$ \\
\hline & $(0.17100)$ & $(0.75261)$ & $(0.02861)$ & $(0.08622)$ & $(0.17268)$ \\
\hline & {$[2.21203]$} & {$[0.68839]$} & {$[-1.59648]$} & {$[-0.96151]$} & {$[2.22003]$} \\
\hline R-squared & 0.517321 & 0.086583 & 0.554616 & 0.227617 & 0.486538 \\
\hline Sum sq. resids & 0.093169 & 1.804768 & 0.002608 & 0.023685 & 0.095012 \\
\hline S.E. equation & 0.047670 & 0.209806 & 0.007976 & 0.024035 & 0.048139 \\
\hline F-statistic & 8.788499 & 0.777276 & 10.21110 & 2.416499 & 7.770028 \\
\hline & & & & &
\end{tabular}

Source: own calculations

Note: Statistical significance at the 0.01 level $\left({ }^{* *}\right)$, at the 0.05 level $\left({ }^{* *}\right)$, at the 0.1 level $\left({ }^{*}\right)$. Standard errors in $($ ) \& t-statistics in [ ].

$$
\begin{aligned}
& D(Y)=-0.006 \cdot[Y(-1)+0.169 \cdot B R E N T(-1)-2.906 \cdot G D P(-1)+9.083 \cdot \operatorname{INE}(-1)-1.856 \cdot \\
& U N(-1)]+0.301 \cdot D(Y(-1))-0.005 \cdot D(B R E N T(-1))-0.485 \cdot D(G D P(-1))-0.574 \cdot \\
& \mathrm{D}(\operatorname{INE}(-1))+0.378 \cdot \mathrm{D}(U N(-1))
\end{aligned}
$$

The VECM estimation results did not show the statistical significance of the correction component for the default rate model. Therefore, the model does not sufficiently explain the convergence to the long-term equilibrium state defined by the cointegration equation. The CointEq1 value $(-0.006)$ indicates that in the case of the long-term disequilibrium of the dependent variable, this series will be adjusted by only $0.6 \%$ during the first quarter. A statistically significant positive relationship between the default rate and the unemployment rate is delayed by one quarter. A negative relationship is between the default rate and GDP with 1 quarter delay, and the same result applies to the INE variable (the effective exchange rate of the Czech crown).

\subsection{The Diagnostics of VECM}

VECM(1) model stationarity conditions are shown in Fig. 1 which shows the inverse values roots of characteristic polynomial of AR model. These values lie within a unit circle, i.e. the VECM(1) model is stationary.

Non-correlatability of the residual component of the estimated VECM(1) model was tested using the LM test. Tab. 6 shows the test values. This test confirms the noncorrelatability of the residual component (at the $5 \%$ significance level, a null hypothesis of non- 


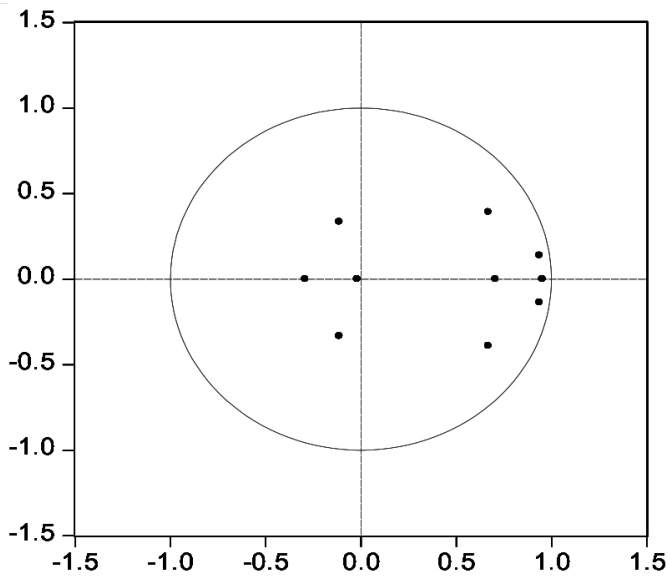

Source: own calculations

\section{Tab. 6:} VECM(1) residual serial correlation LM tests

\begin{tabular}{c|c|c} 
Lags & LM-Stat & p-value \\
\hline 1 & 27.64004 & 0.3247 \\
\hline 2 & 22.74525 & 0.5924 \\
\hline
\end{tabular}

\section{Tab. 7: VECM(1) residual normality test}

\begin{tabular}{c|c|c|c} 
Component & Jarque-Bera & df & p-value \\
\hline 1 & 1.900304 & 2 & 0.3867 \\
\hline 2 & 2.924158 & 2 & 0.2318 \\
\hline 3 & 9.585230 & 2 & 0.0083 \\
\hline 4 & 1.308675 & 2 & 0.5198 \\
\hline 5 & 1.176305 & 2 & 0.5554 \\
\hline Joint & 16.89467 & 10 & 0.0767 \\
\hline
\end{tabular}

Source: own caltulations

correlatability of the residual component is not rejected).

A residual component normality test was conducted using the Jarque-Bera test. The test results are in Tab. 7 . The residual component normality null hypothesis was not rejected at the $5 \%$ significance level.

The null hypothesis of residual component homoscedasticity was not rejected at the $5 \%$ significance level, as the results show 
Chi-sq $=324.7908, \mathrm{df}=300 ;$ Prob. $=0.1556$. The test "No Cross Terms" was performed (only levels and squares).

The residual component is not correlated; residual component heteroscedasticity and residual component non-normality were not demonstrated.

\subsection{Granger Causality}

This chapter deals with the testing of short-term relationships (Granger causality). We test whether one series acts on the other in Granger's sense for the time series pairs ( $Y, B R E N T),(Y, G D P)$, ( $Y, I N E),(Y, U N)$. If the $X$ series acts in Granger's sense on the $Y$ series, then the $X$-series values provide statistically significant information about the future $\mathrm{Y}$-series values. Therefore, it is a tool that evaluates the ability of one series to predict the future values of the other. The hypothesis tested is that the series in question does not act in Granger's sense against an alternative hypothesis that denies the hypothesis tested. Due to the fact that these are quarterly data, Granger causality is tested at the 1,2,3,4 delay. We consider the $5 \%$ significance level. When evaluating Granger causality, it is necessary to work with stationary time series. The results of the series 1 delay test are shown in Tab. 8.

Changes in GDP, INE and UN Granger cause changes in $\mathrm{Y}$ with 1 quarter delay. Changes in $\mathrm{Y}$ Granger cause changes in GDP with 1 quarter delay and 2 quarter delay. Moreover, changes in UN Granger cause changes in $Y$ with 2, 3 and 4 quarter delay.

The time series of the unemployment rate (UN), gross domestic product (GDP) and the effective exchange rate of the Czech crown index (INE) affect the default rate in Granger's sense. Short-term relationships between these variables were confirmed. A short-term relationship between the crude oil price index (BRENT) and the default rate (Y) was not identified and the series are not related.

\subsection{Impulse Response Function}

Impulse-responses trace the effects of structural shocks on the endogenous variables. Each response includes the effect of a specific shock on one of the variables of the system at impact $t$, then on $t+1$, and so on. The results are explained in graphical form as impulse response functions.

Impulse-response function of $Y$ (default rate) on a unit shock of real GDP shows an increase in $Y$ (default rate) variable not opposed by any immediate process (Fig. 2). Impulse-response function of $Y$ on a unit shock of UN (unemployment rate) shows the same result. Reactions of $Y$ on a unit shock of BRENT (oil price index) and INE (index of the effective exchange of the Czech crown) are negative. The system returns to equilibrium for more than 10 quarters in the case on unit shock of variable INE.

Results of variance decomposition of $Y$ are given in Tab. 9. At longer horizons (10 quarters), the contribution of variable GDP shocks to the movements (forecast-error variance) of variable $Y$ (default rate) increases to $8.4 \%$. The contribution of variable BRENT shocks to the movements of $Y$ increases to $4.3 \%$ (at horizons 7 quarters). The largest contribution to the movements of $Y$ (default rate) is of shocks to UN (10.5\%).

\section{Tab. 8: Pairwise Granger causality tests}

\begin{tabular}{l|c|c|c|c}
\multicolumn{1}{c|}{ Null Hypothesis } & Lag & F-Statistic & p-value & $\begin{array}{c}\text { Results for } \\
\mathbf{\alpha}=\mathbf{0 . 0 5}\end{array}$ \\
\hline $\mathrm{D}(\mathrm{BRENT})$ does not Granger Cause D(Y) & 1 & 0.36297 & 0.5500 & NO \\
$\mathrm{D}(\mathrm{Y})$ does not Granger Cause D(BRENT) & & 0.30318 & 0.5847 & NO \\
\hline $\mathrm{D}(\mathrm{GDP})$ does not Granger Cause D(Y) & 1 & 6.42778 & 0.0149 & YES \\
D(Y) does not Granger Cause D(GDP) & & 13.1333 & 0.0007 & YES \\
\hline $\mathrm{D}(\mathrm{INE})$ does not Granger Cause D(Y) & 1 & 4.85304 & 0.0329 & YES \\
$\mathrm{D}(\mathrm{Y})$ does not Granger Cause D(INE) & & 2.74079 & 0.1049 & NO \\
\hline $\mathrm{D}(\mathrm{UN})$ does not Granger Cause D(Y) & 1 & 11.1011 & 0.0018 & YES \\
$\mathrm{D}(\mathrm{Y})$ _does not Granger Cause D(UN) & & 2.24358 & 0.1413 & NO \\
\hline
\end{tabular}




\section{Fig. 2: Response to Cholesky One S.D.Innovations}

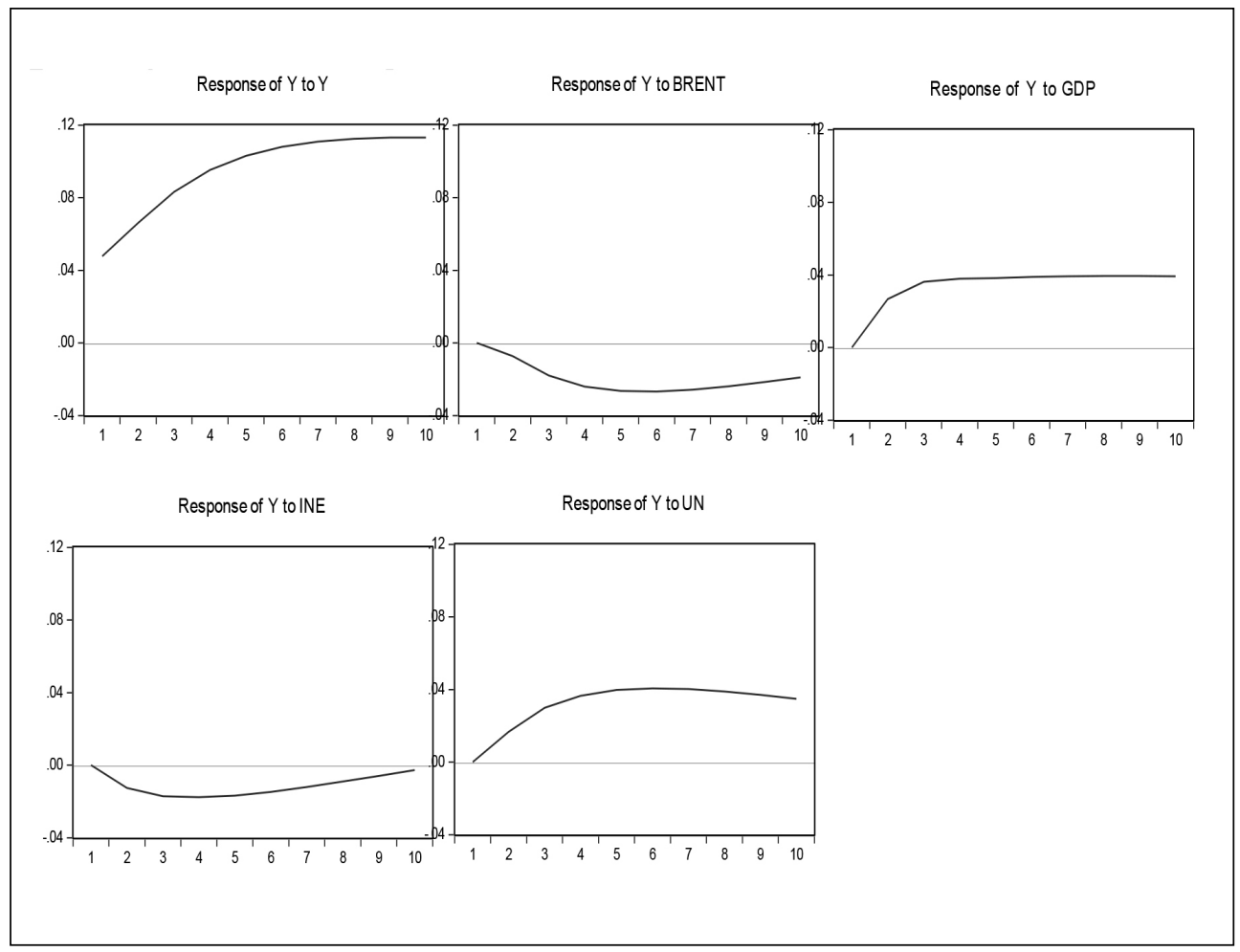

Source: own calculations

\section{Tab. 9: Variance Decomposition of Y (default rate)}

\begin{tabular}{c|c|c|c|c|c|c} 
Period & S.E. & Y & BRENT & GDP & INE & UN \\
\hline 1 & 0.047670 & 100.0000 & 0.000000 & 0.000000 & 0.000000 & 0.000000 \\
\hline 2 & 0.084627 & 92.78546 & 0.737382 & 1.410926 & 2.224427 & 3.841804 \\
\hline 3 & 0.125224 & 86.62650 & 2.390551 & 2.669424 & $\mathbf{2 . 8 8 8 5 7 0}$ & 7.424958 \\
\hline 4 & 0.164780 & 83.50342 & 3.529072 & 2.924179 & 2.827723 & 9.215602 \\
\hline 5 & 0.201427 & 82.10283 & 4.102498 & 3.158557 & 2.591469 & 10.04465 \\
\hline 6 & 0.234800 & 81.58291 & 4.329485 & 4.394507 & 2.304830 & 10.38827 \\
\hline 7 & 0.265032 & 81.54262 & 4.348439 & 5.636712 & 2.018067 & 10.45417 \\
\hline 8 & 0.292438 & 81.76514 & 4.243033 & 6.885803 & 1.753928 & 10.35210 \\
\hline 9 & 0.317379 & 82.12346 & 4.065688 & 7.141162 & 1.523624 & 10.14606 \\
\hline 10 & 0.340212 & 82.54020 & 3.850157 & $\mathbf{8 . 4 0 1 4 0 5}$ & 1.332345 & 9.875897 \\
\hline \multicolumn{7}{l}{ Cholesky Ordering: Y BRENT GDP INE UN }
\end{tabular}




\section{Discussion}

In the case of long-term relationships, surprising results were found regarding GDP and oil price development. GDP growth causes an increase in the default rate in the long run, which is in contradiction with the stated assumption. The GDP grows during the entire period, with the exception of the crisis years from 2008 to 2009. In the case of the default rate development, steady growth is from 2008 to 2009. This is associated with the emergence of new companies without strong capital, which is particularly evident in the period of economic growth. Such companies are more susceptible to bankruptcy even in times of economic growth. Contrary to the assumption, there is also a negative long-term relationship between the development of oil price and the default rate. This result is understandable due to the long-term positive impact of GDP on the default rate. Increases in oil prices are usually associated with a reduction in long-term economic performance.

The existence of three short-term relationships between the time series of the default rate and the time series of the unemployment rate (UN), the real gross domestic product (GDP) and the effective exchange rate of the Czech crown index (INE) in Granger's sense was confirmed. The results show the validity of expected assumptions in the case of short-term relationships. There was a positive correlation between the unemployment rate and the default rate delayed by one quarter. A negative short-term relationship to the default rate was found in the case of the real GDP and in the case of the Czech crown effective exchange rate index with a one-quarter delay.

This article describes the estimation of the VAR(1) model and VECM(1). The model estimation includes a determination of 1 order for delayed variables (BRENT, GDP, INE, $U N, Y$ ) in a vector autoregressive model. This issue has been addressed by a number of authors, such as Alessandri et al. (2009) or Hamerle et al. (2011) who analyse the influence of macroeconomic variables in modelling the default rate in their articles, both in terms of short-term and long-term causal relationships. Nine different variables were used as macroeconomic data. The positive relationship between the oil price development and the default rate was confirmed in the case of long-term relationships. In addition, the long-term negative relationship between the GDP development and the default rate was confirmed, which is in line with the assumption. However, these relationships were not confirmed in this article.

Various macroeconomic indicators are used as explanatory variables in connection with the default rate indicator in the economy. Interest rates and gross domestic product are most often considered. Further information on the issue of explanatory macroeconomic indicators can be found, for example, in Virolainen (2004), Jakubík (2006). Gross domestic product is a basic indicator of the cyclical position of the economy, with its decline or low growth being reflected in the default rate, for example, by negative effects on company profits, employee's wage growth, unemployment or asset prices, which lead to a deterioration in the quality of credit portfolio. The interest rate growth has a similar effect on the default rate, which increases the costs of financing for businesses and households and reduces a market value of assets. In this article, however, the interest rate was not included among the explanatory variables as described in Chapter 3.1 .

\section{Conclusions}

The paper investigates the long-run and short-run causal relationship between the default rate and macroeconomic factors in the Czech Republic through the default rate and macroeconomic indicators in the period from 2005 to 2017. There are used these macroeconomic variables: gross domestic product (GDP), consumer price index $(\mathrm{CPI})$, real interest rate (IR), index of the effective exchange rate of the Czech crown (INE), oil price index (BRENT), unemployment rate (UN) and monetary aggregate M2. Statistically significant relationships between the dependent variable and the individual macroeconomic variables were identified. The resulting model then included variables that showed a statistically significant dependence on the default rate.

Modelling using the cointegration vector autoregressive model for endogenous variables (BRENT, GDP, INE, UN, Y) was used. Estimation of the VECM(1) model is stable, with a relatively high explanatory power. The default rate was defined by the proportion of newly created 'bad' credits to the total volume of credit in the economy. Data source was the ARAD 
database of the Czech National Bank. The data used have the character of a quarterly time series in the period from 2005Q1 to 2017Q1.

The cointegration equation (10) shows that the default rate is positively affected in the long term by GDP and the unemployment rate. GDP growth causes an increase in the default rate in the long run, which is in contradiction with the stated assumption. The positive relationship between the default rate and the unemployment rate is in line with the stated assumption. The equation also shows that there is a negative relationship between the default rate and the Brent crude oil price. This means that the increase in the oil price causes a reduction in the default rate in the long run, which is in contradiction with the assumption. There is also a negative relationship between the default rate and the effective exchange rate of the Czech crown. The results are explained in graphics which show the impulse response functions.

The model revealed that the default rate is increasing in the long run in the case of economic growth. This result seems to be linked to the emergence of new companies without strong capital in periods of economic growth. Another controversial result associated with oil price development appears to stem from the positive impact of GDP on the default rate. Specifically, a higher price of Brent Crude is usually associated with lower long-term economic performance, causing an increase in the default rate (due to the above).

The time series of the unemployment rate (UN), gross domestic product (GDP) and the effective exchange rate of the Czech crown index (INE) affect the default rate in Granger's sense. Short-term relationships between these variables were confirmed. A short-term relationship between the crude oil price index (BRENT) and the default rate (Y) was not identified and the series are not related.

The residual component is not correlated; residual component heteroscedasticity and residual component non-normality were not demonstrated.

The model used for the default rate is theoretically and empirically consistent because the estimated parameters have reasonable signs and values. Empirical results are influenced by the fact that the Czech economy underwent a currency crisis characterized by a typical behaviour of interest rates, monetary indicators, the exchange rate and other indicators in the researched period. The currency crisis also affected the interaction between examined variables. Recent global financial crisis motivates financial market regulators to rethink credit policy management. It would be interesting to make an analysis, which will examine and compare the situation before and after the crisis.

This paper was supported by the Ministry of Education, Youth and Sports Czech Republic within the Institutional Support for Long-term Development of a Research Organization in 2017.

\section{References}

Allessandri, P., Gai, P., Kapadia, S., Mora, N., \& Puhr, C. (2009). Towards a Framework for Quantifying Systemic Stability. International Journal of Central Banking, 5(3), 47-81.

Arlt, J. (1999). Moderni metody modelování ekonomických časových řad. Praha: Grada Publishing.

Arlt, J. (2003). Statistikům a ekonometrům byla udělana Nobelova cena za ekonomii za rok 2003. Informační bulletin České statistické společnosti, 3(14).

Blaschke, W., Jones, M. T., Majnoni, G., \& Martinez Peria, S. (2001). Stress Testing of Financial Systems: An Overview of Issues, Methodologies and FSAP Experiences [IMF Working Paper No. 88]. https://dx.doi. org/10.5089/9781451851168.001.

Chan-Lau, J. A. (2006). FundamentalsBased Estimation of Default Probabilities: A Survey [IMF Working Paper No. 149]. https://dx.doi.org/10.5089/9781451864090.001.

CNB. (2017). ARAD - systém časových rad. Retrieved June 1, 2017, from http://www. cnb.cz/docs/ARADY/HTML/index.htm.

Drehmann, M., \& Quagliariello, M. (2009). Macroeconomic stress testing banks: A survey of methodologies. Stress testing the banking system: Methodologies and applications (pp. 3767). Cambridge: Cambridge University Press. https://dx.doi.org/10.1017/CBO9780511635618.005.

Enders, W. (2010). Applied econometric time series. Hoboken: Wiley.

Engle, R. F., \& Granger, C. W. J. (1987). Co-Integration and Error Correction: Representation, Estimation, and Testing. Econometrica, 55(2), 251-276. https://dx.doi. org/10.2307/1913236. 
Hamerle, A., Dartsch, A., Jobst, R., \& Kilian, P. (2011). Integrating macroeconomic risk factors into credit portfolio models. The Journal of Risk Model Validation, 5(2), 3-24.

Jakubík, P. (2006). Does Credit Risk Vary with Economic Cycles? The Case of Finland [IES Working paper 11/2006].

Jakubík, P. (2007). Macroeconomic Environment Credit Risk. Czech Journal of Economics and Finance, 57(1-2), 60-78.

Johansen, S. (1988). Statistical Analysis of Cointegrating Vectors. Journal of Economic Dynamics and Control, 12(3), 231-254. https:// dx.doi.org/10.1016/0165-1889(88)90041-3.

Johansen, S. (1995). Likelihood-based Inference in Cointegrated VectorAutoregressive Models. Oxford: Oxford University Press.

Kočenda, E., \& Černý, A. (2007). Elements of Time Series Econometrics: An Applied Approach. Prague: Karolinum Press.

Kurzy.cz. (2017). Index nominálního efektivního kurzu koruny. [Data file]. Retrieved June 1, 2017, from http://www.kurzy.cz/cnb/ ekonomika/index-nominalniho-efektivnihokurzu-koruny-2010100.

Lucas, R. E. (1976). Econometric policy evaluation: a critique. In K. Brunner \& A. H. Meltzer (Eds.), The Phillips Curve and Labor Markets, Supplementary Series to the Journal of Monetary Economics (pp. 257-284). NorthHolland.
Marcucci, J., \& Quagliariello, M. (2008). Is Bank Portfolio Riskiness Procyclical? Evidence from Italy using a Vector Autoregression. Journal of International Financial Markets, Institutions and Money, 18(1), 46-63. https://dx.doi.org/10.1016/j.intfin.2006.05.002.

PETROLEUM \& OTHER LIQUIDS. (2017). U.S. Energy Information Administration. [Data file]. Retrieved June 1, 2017, from https://www.eia.gov/dnav/pet/hist/LeafHandler. ash $\mathrm{x} ? \mathrm{n}=$ pet $\& \mathrm{~s}=\mathrm{rclc} 1 \& \mathrm{f}=\mathrm{m}$.

Simons, D., \& Rolwes, F. (2009). Macroeconomic Default Modeling and Stress Testing. International Journal of Central Banking, 5(3), 177-204.

Stavárek, D., \& Vodová, P. (2010). Analýza dlouhodobých vazeb na českém trhu úvěrů. E\&M Ekonomie a Management, 10(3), 83-95.

Virolainen, K. (2004). Macro Stress Testing with a Macroeconomic Credit Risk model for Finland [Bank of Finland Discussion Papers, 18/2004]. https://dx.doi.org/10.2139/ ssrn.622682.

Mgr. Radmila Stoklasová, Ph.D. Silesian University in Opava School of Business Administration in Karviná Department of Informatics and Mathematics Czech Republic stoklasova@opf.slu.cz 


\section{Abstract}

\section{DEFAULT RATE INTHE CZECH REPUBLIC DEPENDING ON SELECTED MACROECONOMIC INDICATORS}

\section{Radmila Stoklasová}

The aim of this article is to analyse which macroeconomic indicators affect the default rate in the Czech Republic in the long run and to create a model that would allow to describe the expected share of the default rate depending on the development of selected macroeconomic indicators on the basis of this analysis. The vector error correction model was used for this purpose to determine both long-term and short-term causal relationships. To create the resulting model, the econometric methodology was used, namely unit root tests, Granger causality for the determination of statistically significant relationships, information criteria and the Johansen cointegration test. The results show the validity of expected assumptions in the case of short-term relationships. There was a positive correlation between the unemployment rate and the default rate delayed by one quarter. A negative short-term relationship to the default rate was found in the case of real GDP and in the case of the Czech crown effective exchange rate index with a one-quarter delay. In the case of long-term relationships, surprising results were found regarding GDP and oil price development. As expected, it was found in the long run that the default rate is positively related to the unemployment and effective exchange rate of the Czech crown. The default rate indicator is one of the inputs of the stress testing model developed by the Czech National Bank. The model is based on the time series of the share of outstanding loans and the total amount of loans, and on selected macroeconomic indicators. Achieved empirical results are influenced by the fact that the Czech economy has undergone the period of currency crisis. The data used have the character of quarterly time series in the period from 2005Q1 to 2017Q1. EViews software version 9 was used for the calculations.

Key Words: ADF test of stationarity, banking sector, cointegration test, default rate, VAR model, VECM.

JEL Classification: C22, C32, E27, G21.

DOI: 10.15240/tul/001/2018-2-005 